\title{
Pedological Characterization of Soils Developed from Volcanic Parent Materials of Northern Province of Rwanda
}

\author{
Providence Uwitonze ${ }^{1, *}$, Balthazar Michael Msanya ${ }^{1}$, Peter Wilson Mtakwa ${ }^{1}$, Solange Uwingabire ${ }^{1}$, \\ Sylvere Sirikare ${ }^{2}$ \\ ${ }^{1}$ Department of Soil and Geological Sciences, College of Agriculture, Sokoine University of Agriculture, Morogoro, Tanzania \\ ${ }^{2}$ Rwanda Agriculture Board, Kigali, Rwanda
}

\section{Email address:}

provy16@gmail.com (P. Uwitonze),bmmsanya@gmail.com (B. M. Msanya), mtakwa@yahoo.com (P. W. Mtakwa), bisoso05@gmail.com (S. Uwingabire), ssirikare@gmail.com (S. Sirikare)

*Corresponding author

\section{To cite this article:}

Providence Uwitonze, Balthazar Michael Msanya, Peter Wilson Mtakwa, Solange Uwingabire, Sylvere Sirikare. Pedological Characterization of Soils Developed from Volcanic Parent Materials of Northern Province of Rwanda. Agriculture, Forestry and Fisheries. Vol. 5, No. 6, 2016, pp. 225-236. doi: 10.11648/j.aff.20160506.13

Received: September 14, 2016; Accepted: September 27, 2016; Published: October 26, 2016

\begin{abstract}
Soils formed from volcanic materials have high potential for agricultural production and support high human population densities. This study was carried out on soils developed from volcanic parent materials of Northern Province of Rwanda aiming largely on pedological characterization but to a certain extent on assessment of potentials of soils for production of major crops in the area. Three representative pedons namely Kinigi Pedon 1 (KNG-P1), Kinigi Pedon 2 (KNGP2) and Gahunga Pedon 1 (GHNG-P1) were identified and described. Sixteen soil samples were collected from different pedogenic horizons and analyzed in the laboratory for physico-chemical properties. Pedons were classified using USDA Soil Taxonomy and FAO-WRB for Soil Resources. Potentials and limitations of the soils were also identified. Results show that soils were shallow to very deep and well drained. Topsoils were very dark coloured with colour values of $\leq 2$ in all pedons. Texture was generally loamy with bulk densities of $<0.47 \mathrm{~g} / \mathrm{cm}^{3}$ in Pedons KNG-P1 and KNG-P2 while they ranged from 0.94 to $1.34 \mathrm{~g} / \mathrm{cm}^{3}$ in Pedon GHNG-P1. Topsoils were medium acid (KNG-P1, KNG-P2) and mildly alkaline (GHNG-P1), with

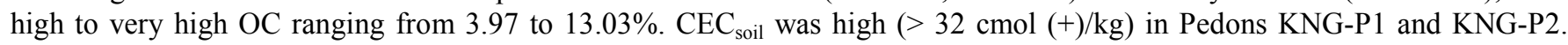
Base saturation was low $(<30 \%)$ in Pedons KNG-P1 and KNG-P2 while it was high $(>50 \%)$ in Pedon GHNG-P1. $\mathrm{pH}_{\mathrm{NaF}}$ was $>9.5$ in Pedons KNG-P1 and KNG-P2 reflecting exchange complex dominated by amorphous materials and/or humus complexes. Phosphorus retention capacity ranged from $6.25 \%$ to $99.58 \%$ and only Pedons KNG-P1 and KNG-P2 met the "andic properties" requirement of PRC $\geq 85 \%$. Melanic index values indicated that these two pedons were characterized more by fulvic than humic acids. Nutrient imbalance with reference to basic cations was common in all studied soils, implying suboptimal nutrient uptake and toxicity. $\mathrm{Fe}_{2} \mathrm{O}_{3}, \mathrm{SiO}_{2}$ and $\mathrm{Al}_{2} \mathrm{O}_{3}$ were the dominant oxides in the studied soils. Degree of weathering of studied soils was low as indicated by their weathering indices. Using field and laboratory data, Pedons KNG-P1 and KNG-P2 classified as Andisols/Andosols and GHNG-P1 as Mollisols/Phaeozems. Land units represented by Pedons KNGP1 and KNG-P2 were rated as marginally suitable while land unit represented by Pedon GHNG-P1 was rated as moderately suitable for the major crops of the area. Application of P fertilizers coupled with efficient placement was recommended to enhance $\mathrm{P}$, and soil conservation should be underscored in study area.
\end{abstract}

Keywords: Pedological Characterization, Soil Morphology and Genesis, Nutrient Balance, Total Elemental Composition, Indices of Degree of Weathering, Soil Classification, Rwanda

\section{Introduction}

Pedological characterization is a pre-requisite for sustainable soil management and proper use of soil resources.
Climatic and other ecological characteristics as well as socioeconomic factors are also important elements in land management. Rwandan soils originate from physicochemical weathering of basic schistose, quartzite, gneiss, 
granite and volcanic rocks that make up the superficial geology of the country [1]. Rwandan soils are naturally fragile and the hilly nature of the Rwandan topography is one of the main factors of soil vulnerability [1]. The first soil survey in Rwanda started in 1955 at Rubona Station [2] and by 1963 , the major soil types of the country had been described [3]. Pedological surveys done in Rwanda have indicated the presence of volcanic ash soils derived dominantly from basic ashes in the volcanic highlands in North-western part of the country [4]. Volcanic ash soils are characterized by properties such as low bulk density, high water retention capacity, an exchange complex dominated by variable charge surfaces, and high anion retention capacity $[5,6,7]$. These soils are highly important for human use and support high human population densities due to their high potential for agricultural production $[5,6,7,8]$. However, some of them produce well below their potential capacity due to farmers' lack of understanding of the nature and properties and proper management of these soils. The northwest region of Rwanda, which is steeply sloping highland experiences heavy rainfall that usually causes erosion, flooding and landslides. Also soil erosion has been accelerated by deforestation [1,9] and bench (radical) terraces were constructed to counteract this problem. Terracing changes the landscape of the area [2]. Due to land scarcity, farmers have converted pasture and woodland into cropland [10] and as reported by $[11,12]$ the land use conversion may cause important changes in physical and chemical properties of soils. Soil erosion coupled with land degradation accelerated by human activities has led to reduction of soil productivity. It has been reported by [13] that agricultural activities such cultivation, tillage, weeding, terracing, sub-soiling, deep plowing, manure, compost and fertilizer applications, liming, drainage and irrigation change the soil chemical, physical, and biological properties. Soils are known to vary greatly across landscapes, and are influenced by topographical features, vegetation types, lithology, climate and land use; and these may influence spatial and temporal variations in soil physico-chemical properties [14]. It has been reported by [5] that farming changes chemical and biological properties of volcanic soils, such as decreasing organic carbon content, enrichment of phosphorus through fertilization, accumulation of heavy metals etc. Due to the anthropogenic activities mentioned above, the earlier land resources surveys of the country [3] may no longer show the reality. This study aimed at the characterization of soils developed on volcanic parent materials to expose the current situation of the area and to provide opportunities for a more rational management of the land resources.

\section{Materials and Methods}

\subsection{Study Site Description}

Table 1. Salient characteristics of studied sites in Northern Province of Rwanda.

\begin{tabular}{|c|c|c|c|c|c|c|c|c|c|c|c|c|}
\hline Pedons $^{1}$ & Village & Sector & District & Coordinates & $\mathbf{A E Z} Z^{2}$ & $\mathbf{A l t}^{3}$ & $\mathbf{M A R}^{4}$ & $\begin{array}{l}\text { Lithology / parent } \\
\text { materials }\end{array}$ & Landform & Land use & $\mathrm{STR}^{5}$ & $\operatorname{SMR}^{6}$ \\
\hline KNG-P1 & Gahura & Kinigi & Musanze & $\begin{array}{l}\text { E } 029^{\circ} 31^{\prime} \\
27.6^{\prime \prime} \\
\text { S } 01^{\circ} 26^{\prime} 10.7^{\prime \prime}\end{array}$ & B & 2629 & $\begin{array}{l}1400- \\
1800\end{array}$ & $\begin{array}{l}\text { Cenozoic volcanic rocks of } \\
\text { Birunga chain Relatively } \\
\text { fresh and some partly } \\
\text { weathered basaltic scoria } \\
\text { appear to dominate }\end{array}$ & Mountainous & $\begin{array}{l}\text { Cultivation, } \\
\text { Tourism, Forest }\end{array}$ & Mesic & Udic \\
\hline KNG-P2 & Kabeza & Kinigi & Musanze & $\begin{array}{l}\mathrm{E} 029^{\circ} 32^{\prime} \\
21.2 . " \\
\text { S } 01^{\circ} 26^{\prime} 13.1^{\prime \prime}\end{array}$ & B & 2471 & $\begin{array}{l}1400- \\
1800\end{array}$ & As above & Hilly & Cultivation & Mesic & Udic \\
\hline GHNG-P1 & Kabindi & Gahunga & Burera & $\begin{array}{l}\text { E } 029^{\circ} 41^{\prime} \\
12.5 . " \\
\text { S } 01^{\circ} 27^{\prime} 00.9^{\prime \prime}\end{array}$ & B & 1936 & 1400 & $\begin{array}{l}\text { Cenozoic volcanic rocks of } \\
\text { Birunga chain. There is } \\
\text { evidence of transported } \\
\text { volcanic rocks mainly } \\
\text { basaltic scoria derived } \\
\text { from nearby Mt. Muhabura } \\
\text { transported by gravity and } \\
\text { fluvial action. Parent } \\
\text { material at site may be } \\
\text { considered as colluvio- } \\
\text { alluvium derived mostly } \\
\text { from volcanic rocks. The } \\
\text { pedon has stratification } \\
\text { typical of alluvial } \\
\text { deposition }\end{array}$ & $\begin{array}{l}\text { Colluvio- } \\
\text { alluvial plain }\end{array}$ & Cultivation & Thermic & Udic \\
\hline
\end{tabular}

1) Soil Pedons: KNG-P1: Kinigi Pedon 1; KNG-P2: Kinigi Pedon 2; GHNG-P1: Gahunga Pedon 1

${ }^{2)}$ AEZ: Agro ecological zone- B: Birunga = located in highland zone and groups the volcanic soils that descend from the limit of the Volcano National Park at an altitude of 2,500 - $1.900 \mathrm{~m}$ near Ruhengeri and even below 1,600 m near Gisenyi. Rainfall varies between 1300 and $1600 \mathrm{~mm}$ and the fertile soils create favourable conditions for agricultural production [10]. The most crops grown are Irish potatoes, green peas, maize, bean, pyrethrum, wheat and sorghum.

${ }^{3)}$ Alt $=$ Altitude in $\mathrm{m}$ a.s.l.

${ }^{4)} \mathrm{MAR}=$ Mean Annual Rainfall in mm.

${ }^{5)} \mathrm{STR}=$ Soil Temperature Regime.

${ }^{6)} \mathrm{SMR}=$ Soil Moisture Regime. 
The study was conducted in Northern Province, Rwanda, with 2 representatives soil pedons located in Musanze District and one representative soil pedon in Burera District. Table 1 gives details of the site characteristics. The representative Pedons KNG-P1 and KNG-P2 are developed from volcanic rocks/materials mainly basaltic scoria while Pedon GHNG-P1 is developed from alluvium of various volcanic materials. The elevation of studied areas ranges between 1936 and $2629 \mathrm{~m}$ with mean annual rainfall ranging from 1400-1800 mm in Musanze District (KNG-P1, KNG$\mathrm{P} 2$ ) and annual average rainfall of $1400 \mathrm{~mm}$ in Burera District (GHNG-P1). Climate of the study area is humid with two dry seasons and two rainy seasons and temperature ranges from 9 to $29^{\circ} \mathrm{C}$. Figure 1 presents the climatic conditions of study area.
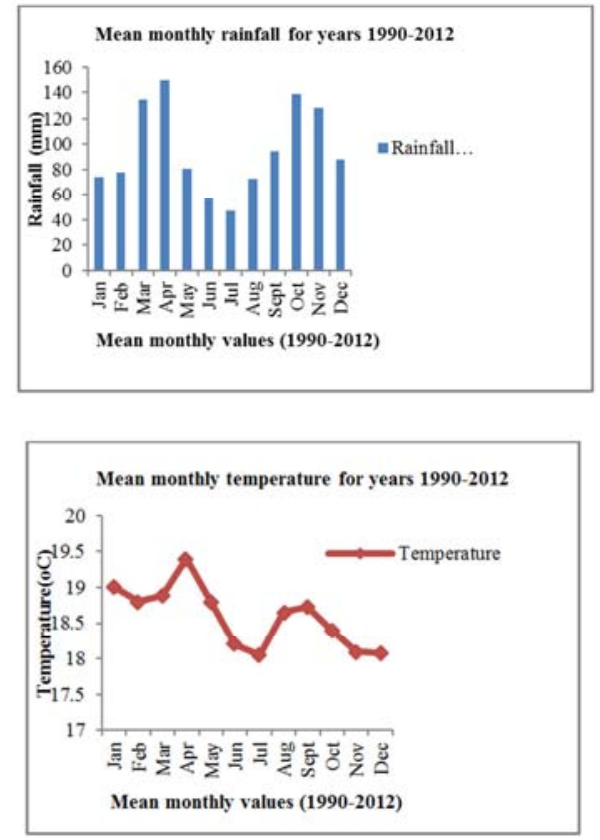

Figure 1. Mean monthly temperature and rainfall of the studied area from 1990-2012.

\subsection{Field Work}

Reconnaissance field survey was carried out by using transect walks, auger observations and descriptions to establish representative study sites on the basis of landforms and other physiographic attributes. Data on land use/crops, landform, parent material, vegetation, elevation, slope gradient and soil morphological characteristics were collected at each observation site. In each identified landform unit, soil observations were made to a maximum depth of 1.0 $\mathrm{m}$ or to a limiting layer to identify soil properties by augering along the transect. These data were filled in forms adopted from the FAO guidelines for soil description [15]. Representative soil profile sites were identified, dug up to 2.0 $\mathrm{m}$ or to a limiting layer, described and sampled according to FAO Guidelines for Soil Profile Description [15]. Georeferencing of profile sites was done using Garmin Global
Positioning System (Model etrex 20). Soil colour was determined using Munsell Color Charts [16]. In each profile pit, undisturbed (core) soil samples were sampled at depths of 0-5 cm, 45-50 cm and 95-100 cm while disturbed samples were taken from all the designated genetic horizons for laboratory physical and chemical analysis.

\subsection{Physical and Chemical Analyses}

Undisturbed core samples were used for determination of bulk density, porosity and moisture retention characteristics. Bulk density was determined by the core method [17]. Particle density was calculated using the mass of the solid particles and the volume they occupy. Mass of the solid particles was obtained by weighing the solid particles and likewise the volume was determined from the mass and density of water displaced by the sample [18]. Total soil porosity was calculated by using the bulk and particle density data. Soil moisture retention characteristics were studied using sand kaolin box for low suction values and pressure apparatus for high suction values [19, 20]. Disturbed soil samples were air-dried and ground to pass through a $2-\mathrm{mm}$ sieve to obtain the fine earth fractions for determination of physical and chemical soil properties. The disturbed soil samples were used for determination of other physical and all chemical properties of soils. Particle size analysis was determined by the hydrometer method [20, 21]. Textural classes were determined using the USDA textural triangle [22]. Penetration resistance was measured using Japanese penetrometer model DIK-5551; the penetration resistance $\mathrm{R}$ $\left(\mathrm{kg} / \mathrm{cm}^{2}\right)$ was calculated as follows:

$$
\mathrm{R}=(100 * \mathrm{x}) /[0.7952(40-\mathrm{x}) 2]
$$

where $\mathrm{x}=\mathrm{mm}$ penetrometer reading.

Soil $\mathrm{pH}$ was measured potentiometrically in water and $1 \mathrm{~N}$ $\mathrm{KCl}$ at a ratio of 1:2.5 weight to volume basis [20, 23]. Electrical conductivity (EC) was measured on a 1:2.5 soil:water suspension using electrical conductivity meter [24]. $\mathrm{pH}$ in $\mathrm{NaF}$ was also determined potentiometrically, but at a ratio of 1:50 weight to volume basis, and $\mathrm{pH}$ measurements were taken after 2 minutes [20, 25]. Organic carbon was determined by the Walkley and Black wet oxidation method [26] and organic carbon was converted to organic matter by multiplying with a factor of 1.724 [27]. Total $\mathrm{N}$ was determined using micro-Kjeldahl digestiondistillation method as described by [28]. Available phosphorus was extracted using Bray and Kurtz-1 method [29] for low $\mathrm{pH}$ soils $\left(\mathrm{pH}_{\text {water }}<7\right)$ and Olsen method for high $\mathrm{pH}$ soils $\left(\mathrm{pH}_{\text {water }}>7\right)$ [30]. Melanic index (MI) was calculated according to the method of [31]. Cation exchange capacity of soil $\left(\mathrm{CEC}_{\text {soil }}\right)$ and exchangeable bases were determined by saturating soil with neutral $1 \mathrm{M} \mathrm{NH}_{4} \mathrm{OAc}$ (ammonium acetate) and the adsorbed $\mathrm{NH}_{4}^{+}$were displaced using $1 \mathrm{M} \mathrm{KCl}$ and then determined by Kjeldahl distillation method for estimation of CEC of soil [32]. Exchangeable bases $\left(\mathrm{Ca}^{2+}, \mathrm{Mg}^{2+}, \mathrm{Na}^{+}\right.$and $\left.\mathrm{K}^{+}\right)$were measured by atomic 
absorption spectrophotometer (AAS) [33]. The total exchangeable bases (TEB) were calculated arithmetically as the sum of the four exchangeable bases $\left(\mathrm{Ca}^{2+}, \mathrm{Mg}^{2+}, \mathrm{Na}^{+}\right.$and $\mathrm{K}^{+}$) for a given soil sample.

The micronutrients $\mathrm{Fe}, \mathrm{Mn}, \mathrm{Zn}$ and $\mathrm{Cu}$ were extracted using buffered $0.005 \mathrm{M}$ DTPA (Diethylene Triamine Pentaacetic Acid) [34], and their concentrations determined by an Atomic Absorption Spectrophotometer (AAS) (UNICAM 919 model). Phosphate retention capacity was determined according to the method of [35]. Total elemental composition of fine earth soil samples and rock samples was determined by X-Ray Fluorescence. Powdered samples were pressed into XRF sample cups and mounted with PANalytical B.V X-Ray film-polyesterpetp. Elemental oxides were measured using PANalytical, Minipal 4 Energy
Dispersive X-Ray Fluorescence Spectrometer (ED-XRF) Model PW4030/45B. Chemical index of alteration (CIA) as an indicator of degree of weathering was calculated for selected horizons using the formula by [36] given as:

$$
\mathrm{CIA}=\left\{\mathrm{Al}_{2} \mathrm{O}_{3} /\left(\mathrm{Al}_{2} \mathrm{O}_{3}+\mathrm{K}_{2} \mathrm{O}+\mathrm{Na}_{2} \mathrm{O}+\mathrm{CaO}\right)\right\} * 100
$$

\subsection{Classification of Soils}

Using field and laboratory data, the soils were classified to family level of the USDA Soil Taxonomy [37] and to tier-2 of the FAO World Reference Base [38].

\section{Results and Discussion}

\subsection{Soil Morphology and Genesis in the Study Area}

Table 2. Selected morphological characteristics of the studied soil pedons.

\begin{tabular}{|c|c|c|c|c|c|c|c|c|c|c|}
\hline $\begin{array}{l}\text { Soil } \\
\text { pedons }{ }^{1}\end{array}$ & Horizon & Depth (cm) & Texture $^{2}$ & Moist colour ${ }^{3}$ & Consistence $^{4}$ & Structure $^{5}$ & Pores $^{6}$ & $\operatorname{Roots}^{7}$ & Rock fragment ${ }^{8}$ & $\begin{array}{l}\text { Horizon } \\
\text { Boundary9 }\end{array}$ \\
\hline \multirow{5}{*}{ KNG-P1 } & Ap1 & $0-35 / 47$ & SL & b (10YR1.7/1) & vfr, sst \& spl & $\begin{array}{l}\text { mo, m, sbk / } \\
\text { mo,f,cr }\end{array}$ & $\mathrm{fm}, \mathrm{m}(\mathrm{f}+\mathrm{vf})$ & $\mathrm{cf}, \mathrm{fm}$ & - & $\mathrm{dw}$ \\
\hline & Ap2 & $35 / 47-87$ & $\mathrm{SL}$ & b (10YR1.7/1) & vfr, sst \& spl & $\begin{array}{l}\text { mo, m, sbk/ } \\
\text { mo, f,cr }\end{array}$ & $\mathrm{fm}, \mathrm{m}(\mathrm{f}+\mathrm{vf})$ & $\mathrm{ff}$ & - & $\mathrm{dw}$ \\
\hline & Ap3 & $87-136 / 140$ & SL & b (10YR1.7/1) & vfr, sst \& spl & $\begin{array}{l}\mathrm{mo}, \mathrm{m}, \\
\mathrm{sbk} / \mathrm{mo}, \mathrm{f}, \mathrm{cr}\end{array}$ & $\mathrm{fm}, \mathrm{m}(\mathrm{f}+\mathrm{vf})$ & vff & $\mathrm{f}(\mathrm{m}-\mathrm{c}), \mathrm{f}, \mathrm{sbk}, \mathrm{v}$ & $\mathrm{cw}$ \\
\hline & $\mathrm{CR}$ & $166 / 210-280+$ & LS & br $(2.5 \mathrm{YR} 2 / 4)$ & - & ssg & $\mathrm{m}(\mathrm{c}+\mathrm{m})$ & vff & $\mathrm{m}(\mathrm{s}+\mathrm{m}+\mathrm{c}), \mathrm{f},(\mathrm{a}+\mathrm{sbk}) \mathrm{v}$ & - \\
\hline & Ap1 & $0-24$ & SL & b (10YR1.7/1) & vfr, nst \& spl & $\mathrm{w}, \mathrm{f}+\mathrm{m}, \mathrm{cr}$ & $\mathrm{fm}, \mathrm{mf}$ & $\mathrm{mc}, \mathrm{mm}, \mathrm{mf}$ & $\mathrm{cc}, \mathrm{f}, \mathrm{sbk}, \mathrm{v}$ & ds \\
\hline \multirow[t]{5}{*}{ KNG-P2 } & Ap2 & $24-40$ & SL & b (10YR1.7/1) & vfr,nst \& spl & $\mathrm{w}, \mathrm{f}+\mathrm{m}, \mathrm{cr}$ & $\mathrm{fm}, \mathrm{mf}$ & $\mathrm{fc}, \mathrm{fm}, \mathrm{mf}$ & $\mathrm{cc}, \mathrm{f}, \mathrm{sbk}, \mathrm{v}$ & cs \\
\hline & RA & $40-93$ & LS & bb (10YR $2 / 2$ & vfr, nst \&spl & $\mathrm{w}, \mathrm{f}+\mathrm{m}, \mathrm{sbk}$ & $\mathrm{fm}, \mathrm{mf}$ & $\mathrm{mf}, \mathrm{fm}$ & $\mathrm{m}, \mathrm{f}, \mathrm{sbk}, \mathrm{v}$ & - \\
\hline & Ap & $0-31 / 40$ & SCL & $\mathrm{b}(10 \mathrm{YR} / 2 / 1)$ & fr, sst \& pl & $\mathrm{mo}, \mathrm{m}+\mathrm{c}, \mathrm{sbk}$ & $\mathrm{cm}, \mathrm{m}(\mathrm{f}+\mathrm{vf})$ & $\mathrm{vfm}, \mathrm{cf}$ & - & $\mathrm{cw}$ \\
\hline & Bw1 & $31 / 40-52 / 65$ & SCL & bb (10YR3/2) & fr, st \& pl & $\mathrm{mo}, \mathrm{m}+\mathrm{c}, \mathrm{sbk}$ & $\mathrm{cm}, \mathrm{m}(\mathrm{f}+\mathrm{vf})$ & $\mathrm{ff}$ & - & $\mathrm{cw}$ \\
\hline & $\mathrm{BC}$ & $52 / 65-71 / 73$ & gSL & $\operatorname{dob}(2.5 Y 3 / 3)$ & fr, sst \& spl & $\mathrm{mo}, \mathrm{m}+\mathrm{c}, \mathrm{sbk}$ & $\mathrm{fm}, \mathrm{m}(\mathrm{f}+\mathrm{vf})$ & vff & $\mathrm{f}, \mathrm{c}, \mathrm{f}, \mathrm{sbk}, \mathrm{v}+\mathrm{m}, \mathrm{m}, \mathrm{f}, \mathrm{r}, \mathrm{v}$ & $\mathrm{cw}$ \\
\hline \multirow[t]{4}{*}{ GHNG-P1 } & $2 \mathrm{CB}$ & $105 / 120-119 / 134$ & gSL & $\operatorname{dob}(2.5 \mathrm{Y} 3 / 33)$ & fr, sst \& spl & $\mathrm{w}, \mathrm{m}+\mathrm{c}, \mathrm{sbk}$ & $\mathrm{fm}, \mathrm{m}(\mathrm{f}+\mathrm{vf})$ & $\mathrm{ff}$ & $\begin{array}{l}\mathrm{f}, \mathrm{c}, \mathrm{f} . \mathrm{sbk}, \mathrm{v}+ \\
\mathrm{c}, \mathrm{m}, \mathrm{f}, \mathrm{sbk}, \mathrm{v}\end{array}$ & $\mathrm{cw}$ \\
\hline & 3Bw3 & $119 / 134-140 / 151$ & SCL & bb (10YR3/2) & fr, st \& pl & $\mathrm{mo}, \mathrm{m}+\mathrm{c}, \mathrm{sbk}$ & $\mathrm{cm}, \mathrm{m}(\mathrm{f}+\mathrm{vf})$ & vff & - & $\mathrm{cw}$ \\
\hline & $3 \mathrm{C}$ & $140 / 151-160$ & $\mathrm{~S}$ & bb (7.5YR2/2) & 1 , nst \& npl & ssg & $\mathrm{cm}, \mathrm{m}(\mathrm{f}+\mathrm{vf})$ & vfvf & $\mathrm{f}, \mathrm{m}, \mathrm{pw}, \mathrm{r}, \mathrm{v}$ & $\mathrm{cw}$ \\
\hline & 4Bw4 & $160-180+$ & SL & bb (10YR2/33) & fr, sst \& spl & $\mathrm{mo}, \mathrm{m}+\mathrm{c}, \mathrm{sbk}$ & $\mathrm{cm}, \mathrm{c}(\mathrm{f}+\mathrm{vf})$ & vff & - & - \\
\hline
\end{tabular}

${ }^{1)}$ Soil pedons: KNG-P1 = Kinigi Pedon 1; KNG-P2 = Kinigi Pedon 2; GHNG-P1 = Gahunga Pedon 1

2) Texture: $\mathrm{SL}=$ Sandy loam, $\mathrm{LS}=$ Loamy sand, $\mathrm{SCL}=$ sandy clay loam, $\mathrm{S}=$ sand, gSL = gravelly sandy loam,

${ }^{3)}$ Moist colour: $\mathrm{b}=$ black; $\mathrm{bb}=$ brownish black; $\mathrm{br}=$ brown; dob = dark olive brown; $\mathrm{db}=$ dark brown

${ }^{4)}$ Consistence: $\mathrm{vfr}=$ very friable; $\mathrm{fr}=$ friable, $\mathrm{l}=$ loose; $\mathrm{nst}=$ nonsticky; $\mathrm{sst}=$ slightly sticky; $\mathrm{st}=\mathrm{sticky} ; \mathrm{npl}=\mathrm{nonplastic} ; \mathrm{spl}=\mathrm{slightly}$ plastic; $\mathrm{pl}=\mathrm{plastic}$

5) Structure:

Grade: $\mathrm{mo}=$ moderate; mo-s = moderate to strong; $\mathrm{w}=$ weak

Size: $\mathrm{m}=$ medium; $\mathrm{m}+\mathrm{c}=$ medium and coarse; $\mathrm{f}+\mathrm{m}=$ fine and medium; $\mathrm{f}=$ fine; $\mathrm{m}=$ medium; $\mathrm{c}=$ coarse

Form: sbk = subangular blocky; $\mathrm{a}+\mathrm{sbk}=$ angular and subangular blocky; $\mathrm{cr}=$ crumby; $\mathrm{ssg}=$ structure less single grained

6) Pores:

Quantity: $\mathrm{m}=$ many; $\mathrm{c}=$ common; $\mathrm{f}=$ few; $\mathrm{vf}=$ very few. Size: $\mathrm{c}=$ coarse; $\mathrm{m}=$ medium; $\mathrm{f}=$ fine; $\mathrm{vf}=$ very fine;

7) Roots:

Quantity: $\mathrm{m}=$ =many; $\mathrm{c}=$ common; $\mathrm{f}=$ few; $\mathrm{vf}=$ very few. Size: $\mathrm{c}=$ coarse; $\mathrm{m}=$ =medium; $\mathrm{f}=$ fine; $\mathrm{v}=$ =very fine

${ }^{8)}$ Rock fragments:

Quantity: $\mathrm{m}=$ many; $\mathrm{c}=$ common; $\mathrm{f}=\mathrm{few}$; $\mathrm{v}=$ =very few. Size: $\mathrm{c}=$ coarse; $\mathrm{m}=$ medium gravel; $\mathrm{f}=$ fine gravel. Weathering: $\mathrm{f}=$ fresh; $\mathrm{pw}=$ partially weathered

Shape: $s b k=$ subangular blocky; $a=$ angular; $r=$ rounded. Nature: $v=$ volcanic

${ }^{9)}$ Horizon boundary: Width: $\mathrm{c}=$ clear; $\mathrm{d}=$ diffuse. Topography: $\mathrm{w}=$ wavy; $\mathrm{s}=$ smooth

Some key morphological properties of the studied pedons are presented in Table 2 . The studied soil pedons were very deep $(>150 \mathrm{~cm})$ except Pedon KNG-P2 which was typically shallow soil $(30-50 \mathrm{~cm})$ resting directly on rock boulders with minor pockets of soil. All studied soils were well drained with moist consistence ranging from very friable to friable except in Pedon GHNG-P1 where one horizon had loose moist consistence, and wet consistence was ranging from non-sticky and non-plastic to sticky and plastic. The topsoils were very dark coloured with colour values of 2 or less in all pedons. The textures of the studied soils were variable within and among profiles but were generally loamy 
or coarser. The structures of the A and B horizons were better developed (crumby, angular or subangular blocky) than those of the CR horizon (KNG-P1) and 3C horizon (GHNG-P1) which were structureless single grained. Both Pedons KNGP1 and KNG-P2 had thixotropic properties typical of volcanic soils. The quantity of roots in the soils decreased with depth and the horizon boundaries were quite distinct, ranging mostly from clear to diffuse with either smooth or wavy horizon topography. A typical feature of Pedon GHNG$\mathrm{P} 1$ is that it shows evidence of stratification and lithological discontinuity in form of buried horizons such as $2 \mathrm{Bw} 2,2 \mathrm{CB}$,
3Bw3, 3C, 4Bw4. The buried horizons reflect different cyclic depositions of soil material detached by gravity from Muhabura Mountain or surrounding area and then transported later by water to the depositional site. This pedon is prone to seasonal flooding during the rainy season. Rounded iron concretions/nodules were observed in KNG$\mathrm{P} 1$. This is probably because the area is located in lower quarter of the mountain and it is possible that there were occasions of waterlogging conditions in the past years.

\subsection{Physical Properties of the Studied Soil Pedons}

Table 3. Soil physical properties of studied pedons.

\begin{tabular}{|c|c|c|c|c|c|c|c|c|c|c|c|}
\hline \multirow{2}{*}{$\begin{array}{l}\text { Profile } \\
\text { No. }\end{array}$} & \multirow{2}{*}{ Horizons } & \multirow{2}{*}{ Depth (cm) } & \multicolumn{3}{|c|}{ Soil texture } & \multirow[t]{2}{*}{$\begin{array}{l}\text { Textural } \\
\text { Classes }\end{array}$} & \multirow{2}{*}{$\begin{array}{l}\text { Silt/clay } \\
\text { Ratio }\end{array}$} & $\begin{array}{l}\text { Bulk } \\
\text { density }\end{array}$ & \multirow[t]{2}{*}{$\begin{array}{l}\text { Particle } \\
\text { density }\end{array}$} & \multirow{2}{*}{$\begin{array}{l}\text { Total } \\
\text { Porosity } \\
\% \\
\end{array}$} & \multirow{2}{*}{$\begin{array}{l}\mathrm{R} \\
\mathrm{kg} / \mathrm{cm}^{2}\end{array}$} \\
\hline & & & $\%$ clay & $\%$ silt & $\%$ sand & & & $\mathrm{g} / \mathrm{cm}^{3}$ & & & \\
\hline \multirow{5}{*}{$\begin{array}{l}\text { KNG- } \\
\text { P1 }\end{array}$} & Ap1 & $0-35 / 47$ & 14.0 & 23.2 & 62.8 & SL & 1.66 & 0.43 & 1.87 & 76.73 & 1.92 \\
\hline & Ap2 & $35 / 47-87$ & 18.1 & 18.4 & 63.5 & SL & 1.02 & 0.41 & 2.00 & 79.44 & 2.94 \\
\hline & Ap3 & $87-136 / 140$ & 18.4 & 18.6 & 63.0 & SL & 1.01 & 0.47 & 1.93 & 75.51 & 2.30 \\
\hline & $\mathrm{Bw}$ & $136 / 140-166 / 210$ & 15.4 & 9.2 & 75.4 & SL & 0.60 & nd & nd & nd & 3.49 \\
\hline & $\mathrm{CR}$ & $166 / 210-280+$ & 8.7 & 5.5 & 85.8 & LS & 0.63 & nd & nd & nd & nd \\
\hline \multirow{2}{*}{$\begin{array}{l}\text { KNG- } \\
\text { P2 }\end{array}$} & Ap2 & $24-40$ & 11.8 & 21.2 & 67.0 & SL & 1.80 & nd & nd & nd & 2.67 \\
\hline & RA & $40-93$ & 9.2 & 11.7 & 79.1 & LS & 1.27 & 0.39 & 1.91 & 79.38 & 2.13 \\
\hline \multirow{7}{*}{$\begin{array}{l}\text { GHNG- } \\
\text { P1 }\end{array}$} & Ap & $0-31 / 40$ & 31.6 & 19.3 & 49.1 & SCL & 0.61 & 0.94 & 2.54 & 63.10 & 3.58 \\
\hline & Bw1 & $31 / 40-52 / 65$ & 22.7 & 23.5 & 53.8 & SCL & 1.04 & 1.06 & 2.58 & 59.03 & 5.84 \\
\hline & $\mathrm{BC}$ & $52 / 65-71 / 73$ & 18.7 & 11.5 & 69.8 & gSL & 0.61 & nd & nd & nd & 7.70 \\
\hline & 2Bw2 & $71 / 73-105 / 120$ & 24.7 & 25.5 & 49.8 & SCL & 1.03 & 1.34 & 2.62 & 48.92 & 5.28 \\
\hline & $2 \mathrm{CB}$ & $105 / 120-119 / 134$ & 16.7 & 9.5 & 73.8 & gSL & 0.57 & nd & nd & nd & 8.77 \\
\hline & $3 \mathrm{C}$ & $140 / 151-160$ & 6.7 & 3.5 & 89.8 & $\mathrm{~S}$ & 0.52 & nd & nd & nd & 7.13 \\
\hline & 4Bw4 & $160-180+$ & 16.7 & 11.5 & 71.8 & SL & 0.69 & nd & nd & nd & 4.79 \\
\hline
\end{tabular}

KNG-P1 = Kinigi Pedon 1, KNG-P2 = Kinigi Pedon 2, GHNG-P1 = Gahunga Pedon 1, R = Penetration resistance, nd = not determined

Physical properties of the studied soil pedons are presented in Table 3. The studied topsoils and subsoils were sandy loam in both Pedons KNG-P1 and KNG-P2. Pedon GHNG-P1 had variable textures with a pattern that reflects lithological discontinuity. The particle size distribution in the three pedons did not show any clear trend with depth. This may be due to the fact that the soils have been formed in very unstable landscapes where trends/paths of pedogenesis are often being disturbed/altered [39]. Topsoil bulk densities of the studied soils ranged from 0.39 to $0.94 \mathrm{~g} / \mathrm{cm}^{3}$ while subsoil bulk densities ranged from 0.40 to $1.06 \mathrm{~g} / \mathrm{cm}^{3}$. Low bulk density values may be attributed to high organic matter and/or the presence of allophane which facilitate the development of porous soil structure [5, 40, 41, 42]. Low bulk density facilitates expansion of plant roots enabling them to extract more water and nutrients from the soil. It also contributes to easy tillage and seedling emergence. The bulk density values observed in the studied pedons particularly those of Pedons KNG-P1 and KNG-P2 are typical of volcanic ash soils which normally have bulk density values $\leq$ $0.90 \mathrm{~g} / \mathrm{cm}^{3}[37,38]$. Topsoil particle density values ranged from 1.83 to $2.54 \mathrm{~g} / \mathrm{cm}^{3}$ whereas they ranged from 1.90 to $2.58 \mathrm{~g} / \mathrm{cm}^{3}$ in subsoils. The low values of particle density in topsoils and subsoils in all horizons of Pedons KNG-P1 and KNG-P2 may be attributed to very high content of organic matter in these pedons. Total porosity ranged from 63.10 to
$78.87 \%$ and from $48.92 \%$ to $79.00 \%$ in studied topsoils and subsoils respectively. Higher values of total porosity in studied topsoils may be linked to relatively higher soil organic matter content. Moreover, the lower total porosity in some subsoil horizons may be due to compaction caused by the weight of the overlying layers. Penetration resistance in the topsoils ranged from 1.92 to $3.58 \mathrm{~kg} / \mathrm{cm}^{2}$ while it ranged from 2.67 to $5.84 \mathrm{~kg} / \mathrm{cm}^{2}$ in subsoils. Soil resistance increases with increase in bulk density. Low penetration resistance in studied topsoils may be attributed to low bulk density. According to $[43,44]$, the topsoils are loose and this facilitates root growth. The mid horizons of Pedon GHNGP1 had medium values of penetration resistance, implying that root growth of some cereal plants may be restricted.

Figure 2 presents moisture characteristic curves of the studied pedons. Soil moisture characteristic curves depend on soil particle size distribution and organic matter content [45]. The soil moisture retention curves of Pedons KNG-P1 and KNG-P2 indicate a high retention capacity with a gradual decrease as the suction potential increases. This may be attributed to high organic matter observed in Pedons KNGP1 and KNG-P2. Soil organic matter enhances soil water retention because of its hydrophilic nature and its positive influence on soil structure [45]. High water retention capacity in these soils may also be attributed to the presence of allophane and allophane-like materials through their fine 
particle size and hollow spherical structure [5]. High water retention capacity enables soils to hold more water, which acts as a moisture reserve for plants during periods of water shortage. Water retention capacity of Pedon GHNG-P1 was lower compared to the other studied pedons. This may be attributed to lower organic matter values observed in this pedon [45].
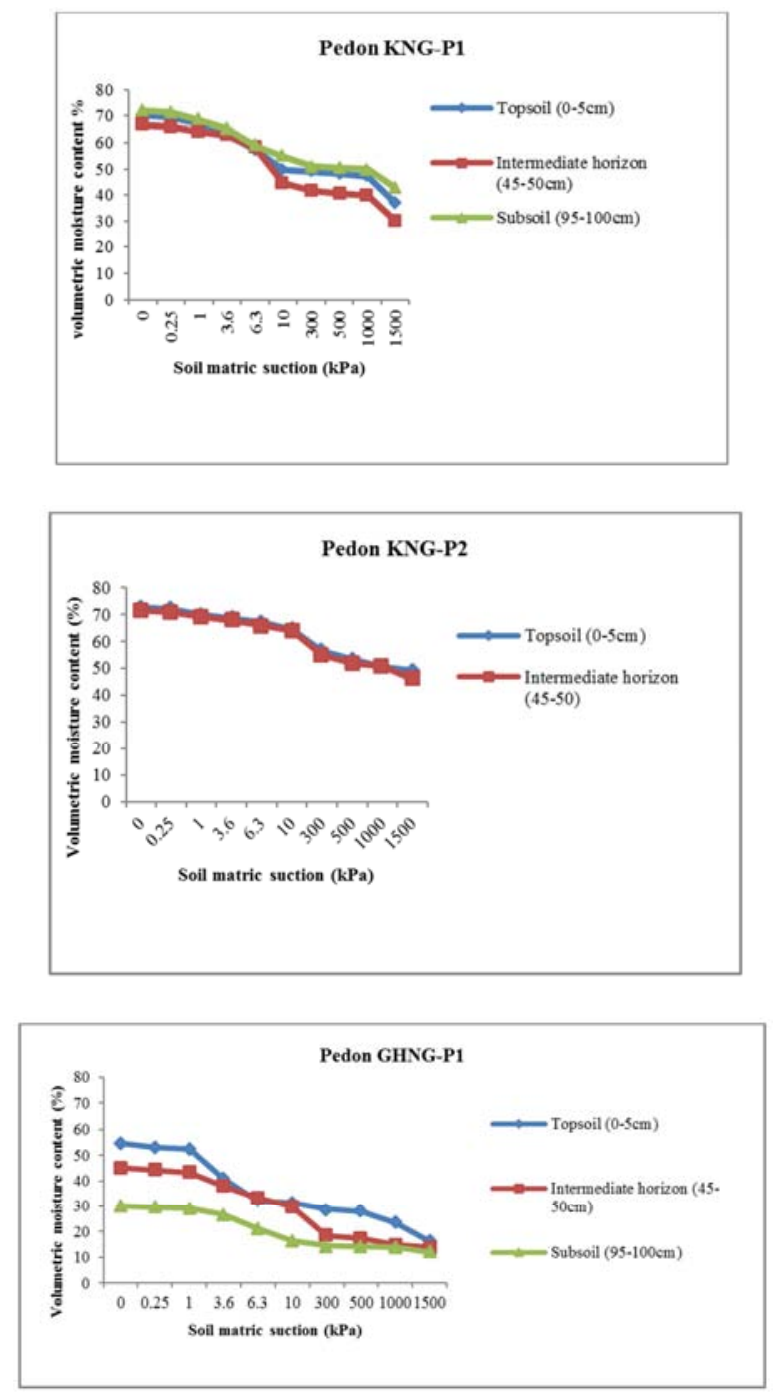

Figure 2. Moisture characteristic curves of studied soils in Northern Province.

\subsection{Soil Chemical Properties}

Some chemical properties of the studied soil pedons are presented in Table 4. Soil $\mathrm{pH}$ is an important chemical property because of its influence on nutrient availability [46]. The $\mathrm{pH}$ values of all the studied soils were higher than 5.5. Topsoil values ranged from 5.57 to 7.41 while they ranged from 5.83 to 7.49 in subsoils. High pH values observed in Pedon GHNG-P1 may be attributed to the application of liming materials or/and continuous addition of less weathered material eroded from the surrounding area [47]. According to [48], these soils were medium acidic to mildly alkaline. Soil acidity is not a serious constraint for agricultural production in these soils as soil $\mathrm{pH}_{\text {water }}$ ranging from 6 to 7.5 has been reported as favourable for most plants [49]. Soil $\mathrm{pH}_{\mathrm{KCl}}$ values were lower than $\mathrm{pH}_{\text {water }}$ values in all studied pedons, indicating that the soils have net negative charge [50]. $\mathrm{pH}_{\mathrm{NaF}}$ values of the studied soils ranged from 11.04 to $11.69,10.96$ to11.77 and from 9.08 to 10.03 in Pedons KNG-P1, KNG-P2 and GHNG-P1, respectively. A soil $\mathrm{pH}_{\mathrm{NaF}} \geq 9.5$ is a strong indicator that amorphous material dominates the soil exchange complex [38]. The high values of $\mathrm{pH}_{\mathrm{NaF}}$ observed in Pedons KNG-P1 and KNG-P2 may be attributed to the presence of large amounts of amorphous and poorly crystalline materials $[5,7,41]$. These attributes are closely linked to soils developed from volcanic parent materials [5, $7,38,41,51]$. Electrical conductivity (EC) values of all the studied pedons were much less than $1.7 \mathrm{dS} / \mathrm{m}$ indicating that the soils have no problems of salinity [48].

The organic carbon (OC) varied within and among pedons. OC contents in topsoils ranged from 3.97 to $13.03 \%$, while in subsoils they ranged from 1.89 to $12.54 \%$. According to [48] topsoil OC was rated as high to very high while the subsoils OC was rated as medium to very high. High values of OC in topsoils may be attributed to the continuous addition of crop residues and the decomposition of roots and plant residues remaining after harvesting on cropped fields. Very high OC values observed in Pedons KNG-P1 and KNG-P2 may be attributed to the tendency of volcanic soils of accumulating organic matter [6]. Cool temperatures of the study area may also retard SOM mineralization which favours appreciable accumulation of organic carbon in soils [46]. Total Nitrogen (TN) contents of the studied soils ranged from $0.36 \%$ to $1.62 \%$ and from $0.22 \%$ to $1.45 \%$ in topsoils and subsoils respectively, both being rated as medium to high [48]. This may be due to accumulation of organic matter in volcanic soils which is the source of $\mathrm{N}$ and other plant nutrients. High TN levels in topsoil may also be attributed to decomposition of plant litter such as crop residues and application of organic manure. The $\mathrm{C} / \mathrm{N}$ ratios of the studied topsoils and subsoils ranged from 8.04 to 11.03 and from 8.59 to 9.75 respectively. According to [49], the $\mathrm{C} / \mathrm{N}$ ratios of the studied topsoil and subsoils were rated as low to medium and low, respectively. $\mathrm{C} / \mathrm{N}$ ratios ranging from 8 to 13 indicate good quality of organic matter [48]. On overall, the studied soils can be said to have good quality organic matter.

Available P ranged from 3.28 to $6.70 \mathrm{mg} \mathrm{P} / \mathrm{kg}, 3.49$ to 4.39 $\mathrm{mg} \mathrm{P} / \mathrm{kg}$ and from 1.46 to $65.14 \mathrm{mg} \mathrm{P} / \mathrm{kg}$ respectively in Pedons KNG-P1, KNG-P2 and GHNG-P1. According to [49], available $P$ is low in all studied horizons of Pedons KNG-P1 and KNG-P2. This may be due to adsorption of phosphorus by amorphous oxides (iron and aluminum oxides) and allophane resulting in the formation of insoluble phosphorus compounds, making it sparingly available for plant uptake [5], and/or it may be attributed to the nature of rocks and minerals that made the parent materials [42]. In Pedon GHNG-P1, available P ranged from low to high [52]. The high values of available $P$ particularly in the topsoil of this pedon may be attributed to anthropogenic activities such the application of $\mathrm{P}$ fertilizers [39]. Phosphorus retention 
capacity (PRC) ranged from 98 to $99.58 \%$ in Pedon KNG$\mathrm{P} 1,96.58$ to $99.42 \%$ in Pedon KNG-P2 and 6.25 to $49 \%$ in Pedon GHNG-P1 (Table 4). The high P retention values in Pedons KNG-P1 and KNG-P2 may be related to the high content of active $\mathrm{Al}$ and active $\mathrm{Fe}[5,40,41]$. The capacity of soil material to retain large amounts of phosphate is also due to the very high specific surface area of the amorphous minerals [53]. Pedon GHNG-P1 had low values of $\mathrm{P}$ retention capacity $(<50 \%)$. According to $[37,38]$, Pedons KNG-P1 and KNG-P2 met the $\mathrm{P}$ retention capacity requirement for the definition of andic properties. The results suggest that in soils with high PRC, high rate of $\mathrm{P}$ fertilizers should be applied therefore to correct for the amount of $\mathrm{P}$ that would be fixed by the soil and leave amounts that would be available to plants.

Table 4. Some selected chemical properties of pedons from selected areas in Northern Province of Rwanda.

\begin{tabular}{|c|c|c|c|c|c|c|c|c|c|c|c|c|}
\hline \multirow{2}{*}{$\begin{array}{l}\text { Pedon } \\
\text { No. }\end{array}$} & \multirow{2}{*}{ Horizons } & \multirow{2}{*}{$\begin{array}{c}\text { Depth } \\
\text { (cm) }\end{array}$} & \multicolumn{3}{|l|}{ pH } & \multirow{2}{*}{$\begin{array}{l}\text { EC } \\
d S / m\end{array}$} & \multirow{2}{*}{$\begin{array}{l}\mathrm{OC} \\
\% \\
\end{array}$} & \multirow[t]{2}{*}{ OM } & \multirow[t]{2}{*}{$\mathbf{N}$} & \multirow{2}{*}{$\begin{array}{l}\text { C/N } \\
\text { Ratio }\end{array}$} & \multirow{2}{*}{$\begin{array}{l}\text { Avail P } \\
\mathrm{mg} \mathrm{P} / \mathrm{kg}\end{array}$} & \multirow{2}{*}{$\begin{array}{l}{ }^{* P R C} \\
\%\end{array}$} \\
\hline & & & $\mathrm{H}_{2} \mathrm{O}$ & $\mathrm{KCl}$ & $\mathrm{NaF}$ & & & & & & & \\
\hline \multirow{6}{*}{ KNG-P1 } & Ap1 & $0-35 / 47$ & 5.57 & 4.47 & 11.64 & 0.13 & 11.67 & 20.12 & 1.13 & 10.33 & 6.39 & 99.25 \\
\hline & Ap2 & $35 / 47-87$ & 5.90 & 4.54 & 11.65 & 0.08 & 10.04 & 17.31 & 1.03 & 9.75 & 6.70 & 98.00 \\
\hline & Ap3 & $87-136 / 140$ & 6.02 & 4.73 & 11.42 & 0.10 & 11.13 & 19.19 & 1.11 & 10.03 & 4.08 & 98.00 \\
\hline & $\mathrm{Bw}$ & $136 / 140-166 / 210$ & 6.40 & 5.01 & 11.69 & 0.09 & 6.99 & 12.05 & 0.75 & 9.32 & 3.97 & 98.00 \\
\hline & $\mathrm{CR}$ & $166 / 210-280+$ & 6.83 & 5.20 & 11.04 & 0.08 & 0.53 & 0.91 & 0.06 & 8.83 & 3.28 & 99.58 \\
\hline & Ap1 & $0-24$ & 5.78 & 4.31 & 10.96 & 0.20 & 13.03 & 22.46 & 1.62 & 8.04 & 4.39 & 96.58 \\
\hline KNG-P2 & RA & $40-93$ & 5.98 & 4.56 & 11.77 & 0.08 & 9.64 & 16.62 & 0.89 & 10.83 & 3.49 & 99.42 \\
\hline \multirow{7}{*}{ GHNG-P1 } & Ap & $0-31 / 40$ & 7.41 & 5.96 & 10.02 & 0.19 & 3.97 & 6.84 & 0.36 & 11.03 & 65.14 & 39.25 \\
\hline & Bw1 & $31 / 40-52 / 65$ & 7.49 & 5.85 & 10.03 & 0.11 & 1.89 & 3.26 & 0.22 & 8.59 & 55.28 & 49.00 \\
\hline & $\mathrm{BC}$ & $52 / 65-71 / 73$ & 7.40 & 5.82 & 9.73 & 0.06 & 0.69 & 1.19 & 0.09 & 7.67 & 12.53 & 35.50 \\
\hline & $2 \mathrm{Bw} 2$ & $71 / 73-105 / 120$ & 7.37 & 5.78 & 9.74 & 0.06 & 0.94 & 1.62 & 0.13 & 7.23 & 8.43 & 42.00 \\
\hline & $2 \mathrm{CB}$ & $105 / 120-119 / 134$ & 7.25 & 5.68 & 9.50 & 0.06 & 0.22 & 0.38 & 0.06 & 3.67 & 3.93 & 16.75 \\
\hline & 3Bw3 & $119 / 134-140 / 151$ & 7.51 & 5.68 & 9.49 & 0.06 & 0.43 & 0.74 & 0.06 & 7.17 & 4.27 & 27.76 \\
\hline & $3 \mathrm{C}$ & $140 / 151-160$ & 7.44 & 5.61 & 9.08 & 0.04 & 0.00 & 0.00 & 0.04 & 0.00 & $\operatorname{tr}$ & 6.25 \\
\hline
\end{tabular}

KNG-P1 = Kinigi Pedon 1, KNG-P2 = Kinigi Pedon 2, GHNG-P1 = Gahunga Pedon 1, tr $=$ Trace

$* \mathrm{PRC}=$ Phosphate retention capacity

\subsection{Exchangeable Cations, Related Properties and Extractable Micronutrients of the Studied Soils}

Exchangeable cations and related properties of the studied soils are given in Table 5. Cation exchange capacity (CEC) is an overall assessment of soil potentiality, which assesses the soil's possible response to fertilizers. It is a guide in identifying the kind of clay minerals and the impact of SOM in terms of both quantity and quality [52]. Topsoil CEC ranged from 31.40 to $56.80 \mathrm{cmol}(+) / \mathrm{kg}$ and from 32.0 to $52.40 \mathrm{cmol}(+) / \mathrm{kg}$ in subsoil, both being rated as high to very high according to [52]. This high CEC values may be related to clay mineralogical composition, and accumulation of organic matter [51]. Percent base saturations (PBS) of the studied soils ranged from 14.04 to $29.69 \%, 7.53$ to $13.75 \%$ and from 43.95 to $77.74 \%$ respectively in Pedons KNG-P1, KNG-P2 and GHNG-P1. PBS in both subsoils and topsoils was rated as low to high [54]. On the overall, the PBS values are low in Pedons KNG-P1, KNG-P2 while they are high in Pedon GHNG-P1. The low BS values observed in Pedons KNG-P1 and KNG-P2 may be attributed to poor cultivation practices, poor soil and water conservation and inadequate supply of fertilizer to replenish nutrients removed by crops [55] and/or may be attributed to the nature of the parent rocks [42]. Therefore application of the limiting nutrients is inevitable.

Extractable Fe was very high in both topsoils and subsoils of studied pedons [56]. High amounts of extractable Fe may be linked to the nature of soil forming rocks and minerals.
Extractable $\mathrm{Cu}$ of the studied soils ranged from 0.52 to 0.87 $\mathrm{mg} / \mathrm{kg}, 0.64$ to $1.11 \mathrm{mg} / \mathrm{kg}$ and from 0.28 to $2.53 \mathrm{mg} / \mathrm{kg}$ in Pedons KNG-P1, KNG-P2, and GHNG-P1, respectively. According to [56], extractable $\mathrm{Cu}$ in the topsoils was high while it was rated as medium to high in subsoils. According to [52], deficiency level of $\mathrm{Cu}$ in soils is $0.75 \mathrm{mg} / \mathrm{kg}$. Therefore topsoils of the studied pedons were not deficient in $\mathrm{Cu}$. Topsoil extractable $\mathrm{Zn}$ ranged from 1.78 to $7.08 \mathrm{mg} / \mathrm{kg}$ which was rated as medium to very high while it was rated as low $(0.91 \mathrm{mg} / \mathrm{kg})$ to medium $(2.24 \mathrm{mg} / \mathrm{kg})$ in subsoils in all studied pedons. Topsoil extractable $\mathrm{Mn}$ was rated as medium to very high while it was low to medium in subsoils in all studied pedons. There was no clear trend of extractable micronutrients with soil depth except in Pedon KNG-P2 where the extractable micronutrients decreased with soil depth. The high amounts of extractable micronutrients observed in this study, may be attributed to the soil forming rocks and minerals [42]. Deficiency and toxicity of these elements may result from certain soil conditions such as soil $\mathrm{pH}$, redox potential, texture, organic matter and environmental factors which either increase or decrease the solubility and the availability of these elements [42, 49, 52].

Melanic index values of the studied pedons are presented in Table 5. Melanic index (MI) helps to differentiate melanic from fulvic Andosols [31]. The MI values of the studied pedons in topsoils and subsoils of Pedons KNG-P1 and KNG-P2 (soils which showed andic properties) were much greater than 1.7 indicating that the studied soils were dominated by fulvic acid [37, 38]. 
Table 5. Exchangeable cations and related properties and micronutrient contents of the studied soils.

\begin{tabular}{|c|c|c|c|c|c|c|c|c|c|c|c|c|c|c|}
\hline \multirow{3}{*}{ Pedon No. } & \multirow{3}{*}{ Horizons } & \multirow{3}{*}{ Depth (cm) } & \multicolumn{5}{|c|}{ Exchangeable bases } & \multirow{3}{*}{$\mathrm{CEC}_{\text {soil }}$} & \multicolumn{6}{|c|}{ Extractable micronutrients } \\
\hline & & & Ca & Mg & $\mathbf{K}$ & $\mathrm{Na}$ & TEB & & \multirow{2}{*}{$\begin{array}{l}\text { BS } \\
\% \\
\end{array}$} & \multirow[t]{2}{*}{$\mathrm{Fe}$} & \multirow{2}{*}{$\frac{\mathrm{Cu}}{\mathrm{n}}$} & $\mathbf{Z n}$ & \multirow[t]{2}{*}{ Mn } & \multirow[t]{2}{*}{$\begin{array}{l}\text { Melanic } \\
\text { index }\end{array}$} \\
\hline & & & \multicolumn{5}{|c|}{$(\mathrm{cmol}(+) / \mathrm{kg})$} & & & & & $\mathrm{mg} / \mathrm{kg}$ & & \\
\hline \multirow{5}{*}{ KNG-P1 } & Ap1 & $0-35 / 47$ & 6.63 & 1.34 & 0.05 & 0.12 & 8.14 & 56.6 & 14.38 & 54.74 & 0.87 & 1.78 & 2.62 & 2.55 \\
\hline & Ap2 & $35 / 47-87$ & 9.92 & 0.83 & 0.00 & 0.09 & 10.84 & 52.4 & 20.69 & 56.49 & 0.64 & 2.24 & 2.62 & 2.73 \\
\hline & Ap3 & $87-136 / 140$ & 15.32 & 1.64 & 0.03 & 0.11 & 17.10 & 57.6 & 29.69 & 78.07 & 0.87 & 4.17 & 4.48 & 2.71 \\
\hline & $\mathrm{Bw}$ & $136 / 140-166 / 210$ & 9.28 & 2.06 & 0.00 & 0.10 & 11.44 & 61.6 & 18.57 & 60.53 & 0.52 & 0.35 & 2.62 & 2.91 \\
\hline & $\mathrm{CR}$ & $166 / 210-280+$ & 3.24 & 1.08 & 0.11 & 0.09 & 4.52 & 32.2 & 14.04 & 56.14 & 0.52 & 0.66 & 2.19 & 3.27 \\
\hline \multirow{3}{*}{ KNG-P2 } & Ap1 & $0-24$ & 6.31 & 0.61 & 0.34 & 0.14 & 7.40 & 56.8 & 13.03 & 78.07 & 1.11 & 2.54 & 1.61 & 2.23 \\
\hline & Ap2 & $24-40$ & 6.42 & 0.25 & 0.14 & 0.12 & 6.93 & 50.4 & 13.75 & 51.75 & 0.64 & 0.91 & 1.04 & 2.29 \\
\hline & RA & $40-93$ & 4.09 & 0.40 & 0.04 & 0.11 & 4.64 & 61.6 & 7.53 & 33.25 & 0.64 & 0.2 & 0.61 & 2.72 \\
\hline \multirow{8}{*}{ GHNG-P1 } & Ap & $0-31 / 40$ & 16.17 & 3.04 & 5.09 & 0.11 & 24.41 & 31.4 & 77.74 & 68.33 & 1.58 & 7.08 & 7.2 & nd \\
\hline & Bw1 & $31 / 40-52 / 65$ & 14.79 & 1.94 & 5.35 & 0.14 & 22.22 & 32.0 & 69.44 & 82.46 & 1.58 & 2.13 & 3.05 & nd \\
\hline & $\mathrm{BC}$ & $52 / 65-71 / 73$ & 7.16 & 1.39 & 2.62 & 0.20 & 11.37 & 18.6 & 61.13 & 42.98 & 0.87 & 1.01 & 1.76 & nd \\
\hline & $2 \mathrm{Bw} 2$ & 71/73-105/120 & 12.78 & 2.87 & 1.91 & 0.24 & 17.80 & 26.6 & 66.92 & 6.49 & 2.53 & 1.73 & 2.04 & nd \\
\hline & $2 \mathrm{CB}$ & $105 / 120-119 / 134$ & 6.00 & 1.79 & 1.96 & 0.17 & 9.92 & 16.0 & 62.00 & 34.21 & 1.46 & 0.81 & 1.61 & nd \\
\hline & 3Bw3 & $119 / 134-140 / 151$ & 7.69 & 2.22 & 2.87 & 0.18 & 12.96 & 26.6 & 48.72 & 42.98 & 1.58 & 0.35 & 1.61 & nd \\
\hline & $3 \mathrm{C}$ & $140 / 151-160$ & 2.82 & 0.70 & 1.40 & 0.09 & 5.01 & 11.4 & 43.95 & 11.75 & 0.28 & 0.5 & 0.75 & nd \\
\hline & $4 \mathrm{Bw} 4$ & $160-180+$ & 5.57 & 1.64 & 3.02 & 0.11 & 10.34 & 16.8 & 61.55 & 30.61 & 1.11 & 0.71 & 1.04 & nd \\
\hline
\end{tabular}

KNG-P1= Kinigi Pedon1, KNG-P2= Kinigi Pedon 2, GHNG-P1= Gahunga Pedon 1 nd = not determined

\subsection{Nutrient Balance of the Studied Soils}

Soil nutrient ratios in the studied pedons are presented in Table 6. The effects of the major cations in soils on plant growth are often closely interlinked [52]. Other than the absolute amounts of $\mathrm{Ca}, \mathrm{Mg}$, and $\mathrm{K}$ in the soil, the relative amounts between these three elements is a measure of the general availability of nutrients [57]. In particular the ratios $\mathrm{Ca} / \mathrm{Mg}, \mathrm{Mg} / \mathrm{K}$ and $\mathrm{K} / \mathrm{TEB}$ and $\mathrm{Ca} / \mathrm{TEB}$ are important. Nutrient imbalances influence nutrient uptake by inducing deficiencies of nutrients which may be present in the soil in good quantities [58]. $\mathrm{Ca} / \mathrm{Mg}$ ratios of the studied pedons ranged from 3 to $11.95,10.23$ to 25.68 and from 3.35 to 7.62 in Pedons KNGP1, KNG-P2 and GHNG-P1, respectively. The optimum range of $\mathrm{Ca} / \mathrm{Mg}$ ratios for most crops is 2 to 4 [48]. Topsoils and subsoils of the studied pedons had ratios above the optimal levels. This may limit the uptake of $\mathrm{Mg}$ to plants. If the $\mathrm{Ca} / \mathrm{Mg}$ ratio exceeds 5:1, the availability of $\mathrm{Mg}$ and $\mathrm{P}$ is reduced [52]. This is the case for Pedon KNG-P2, and for some horizons of
Pedons KNG-P1 and GHNG-P1. The studied pedons had $\mathrm{Ca} / \mathrm{TEB}$ ratios of $>0.5$ throughout all horizons. This may affect the uptake of other bases particularly $\mathrm{Mg}$ and/or $\mathrm{K}$ due to $\mathrm{Ca}$ induced deficiency [52]. $\mathrm{Mg} / \mathrm{K}$ ratios of the studied pedons ranged from 9.82 to $54.67,1.79$ to 10.00 and from 0.36 to 1.50 in Pedons KNG-P1, KNG-P2 and GHNG-P1, respectively. According to [48], 1 to 4 is the optimum range of $\mathrm{Mg} / \mathrm{K}$ for nutrient uptake by plants. Only Pedon KNG-P2 had the optimum range of $\mathrm{Mg} / \mathrm{K}$. Topsoil $\% \mathrm{~K} / \mathrm{TEB}$ ranged from 0.61 to $20.85 \%$ while it ranged from 0 to $24.08 \%$ in subsoils. [52] reported that the favourable K/TEB ratio for most tropical crops is $2 \%$ or more. Therefore soils represented by Pedons KNG-P2 and GHNG-P1 are in favourable range of K/TEB ratio for most tropical crops. On the overall, nutrient ratios observed in the studied pedons indicate nutrient imbalance and will thus affect negatively nutrient availability. According to [59], application of manures and inorganic fertilizers, adoption of crop rotation can improve nutrient availability.

Table 6. Nutrient ratios of the studied soils.

\begin{tabular}{|c|c|c|c|c|c|c|}
\hline Profile & Horizons & Depth (cm) & Ca/TEB & $\mathrm{Ca} / \mathrm{Mg}$ & $\mathrm{Mg} / \mathrm{K}$ & $\%($ K/TEB $)$ \\
\hline \multirow[t]{5}{*}{ KNG-P1 } & Ap1 & $0-35 / 47$ & 0.81 & 4.95 & 26.80 & 0.61 \\
\hline & Ap2 & $35 / 47-87$ & 0.92 & 11.95 & - & 0.00 \\
\hline & Ap3 & $87-136 / 140$ & 0.90 & 9.34 & 54.67 & 0.18 \\
\hline & $\mathrm{Bw}$ & $136 / 140-166 / 210$ & 0.81 & 4.50 & - & 0.00 \\
\hline & CR & $166 / 210-280+$ & 0.72 & 3.00 & 9.82 & 2.43 \\
\hline \multirow[t]{2}{*}{ KNG-P2 } & Ap1 & $0-24$ & 0.85 & 10.34 & 1.79 & 4.59 \\
\hline & Ap2 & $24-40$ & 0.93 & 25.68 & 1.79 & 2.02 \\
\hline \multirow[t]{7}{*}{ GHNG-P1 } & Ap & $0-31 / 40$ & 0.66 & 5.32 & 0.60 & 20.85 \\
\hline & Bw1 & $31 / 40-52 / 65$ & 0.67 & 7.62 & 0.36 & 24.08 \\
\hline & $\mathrm{BC}$ & $52 / 65-71 / 73$ & 0.63 & 5.15 & 0.53 & 23.04 \\
\hline & 2Bw2 & $71 / 73-105 / 120$ & 0.72 & 4.45 & 1.50 & 10.73 \\
\hline & $2 \mathrm{CB}$ & $105 / 120-119 / 134$ & 0.60 & 3.35 & 0.91 & 19.76 \\
\hline & 3Bw3 & $119 / 134-140 / 151$ & 0.59 & 3.46 & 0.77 & 22.15 \\
\hline & $3 \mathrm{C}$ & $140 / 151-160$ & 0.56 & 4.03 & 0.50 & 27.94 \\
\hline
\end{tabular}

KNG-P1= Kinigi Pedon1, KNG-P2=Kinigi Pedon2, GHNG-P1=Gahunga Pedon1 


\subsection{Total Elemental Composition of the Studied Soils}

Table 7. Total elemental concentrations of the studied soil and rock samples.

\begin{tabular}{|c|c|c|c|c|c|c|c|c|c|c|c|c|c|c|}
\hline \multirow{2}{*}{ Profile } & \multirow{2}{*}{ Horizon } & \multirow{2}{*}{$\begin{array}{l}\text { Depth } \\
\text { cm }\end{array}$} & $\mathrm{SiO}_{2}$ & $\mathbf{A l}_{2} \mathrm{O}_{3}$ & $\mathrm{Fe}_{2} \mathrm{O}_{3}$ & $\mathrm{~K}_{2} \mathbf{O}$ & $\mathrm{CaO}$ & $\mathrm{TiO}_{2}$ & MnO & $\mathbf{P}_{2} \mathbf{O}_{5}$ & MgO & $\mathrm{Na}_{2} \mathrm{O}$ & Total & CIA \\
\hline & & & \multicolumn{4}{|c|}{$\%$} & & & & & & & & \\
\hline \multirow{3}{*}{ KNG-P1 } & Ap1 & $0-35 / 47$ & 29.0 & 18.0 & 37.09 & 0.79 & 3.98 & 6.92 & 0.74 & 1.4 & 0.01 & 0.01 & 97.94 & 79.01 \\
\hline & $\mathrm{Bw}$ & $136 / 140-166 / 210$ & 23.0 & 21.0 & 40.17 & 0.76 & 4.39 & 7.56 & 0.71 & 1.4 & 0.02 & 0.02 & 99.03 & 80.26 \\
\hline & $\mathrm{CR}$ & $166 / 210-280$ & 26.0 & 15.0 & 37.81 & 0.71 & 10.5 & 7.96 & 0.62 & 0.0 & 0.08 & 0.01 & 98.69 & 57.20 \\
\hline \multirow{2}{*}{ KNG-P2 } & Ap1 & $0-24$ & 37.2 & 8.0 & 38.07 & 1.00 & 4.55 & 6.81 & 0.51 & 1.5 & 0.01 & 0.02 & 97.66 & 58.98 \\
\hline & RA & $40-93$ & 17.0 & 19.0 & 45.88 & 0.68 & 5.00 & 8.30 & 0.69 & 1.2 & 0.01 & 0.01 & 97.77 & 76.95 \\
\hline \multirow{5}{*}{ GHNG-P1 } & Ap1 & $0-31 / 40$ & 32.2 & 13.0 & 28.03 & 3.29 & 12.7 & 6.14 & 0.55 & 1.9 & 0.06 & 0.03 & 97.89 & 44.80 \\
\hline & Bw1 & $31 / 40-52 / 65$ & 31.0 & 13.0 & 29.86 & 3.28 & 11.9 & 6.49 & 0.57 & 1.6 & 0.01 & 0.02 & 97.72 & 46.11 \\
\hline & $2 \mathrm{Bw} 2$ & $71 / 73-105 / 120$ & 33.7 & 14.0 & 28.24 & 3.03 & 11.8 & 6.16 & 0.53 & 1.2 & 0.04 & 0.07 & 98.77 & 48.45 \\
\hline & $3 \mathrm{Bw} 3$ & $119 / 134-140 / 151$ & 36.6 & 15.0 & 26.65 & 3.12 & 10.9 & 5.77 & 0.39 & $0 . p$ & 0.06 & 0.01 & 98.50 & 51.67 \\
\hline & $3 \mathrm{C}$ & $140 / 151-160$ & 34.9 & 12.0 & 26.27 & 4.26 & 14.6 & 6.21 & 0.44 & 0.0 & 0.09 & 0.02 & 98.79 & 38.87 \\
\hline \multicolumn{15}{|c|}{ Rocks samples } \\
\hline KNG-P1 & _- & - & 27.7 & 13.0 & 29.98 & 2.69 & 18.3 & 7.13 & 0.43 & 0.0 & 0.09 & 0.03 & 99.35 & 38.21 \\
\hline KNG-P2 & - & - & 27.7 & 13.0 & 29.98 & 2.69 & 18.3 & 7.13 & 0.43 & 0.0 & 0.09 & 0.03 & 99.35 & 38.21 \\
\hline GHNG-P1 & & & 39.0 & 0.0 & 28.58 & 6.32 & 16.9 & 6.85 & 0.46 & 0.0 & 0.08 & 0.02 & 98.21 & 0.00 \\
\hline
\end{tabular}

KNG-P1= Kinigi Pedon 1 KNG-P2= Kinigi Pedon 2 GHNG-P1= Gahunga Pedon 1

Total elemental composition of the studied soils are presented in Table 7. $\mathrm{Fe}_{2} \mathrm{O}_{3}, \mathrm{SiO}_{2}$ and $\mathrm{Al}_{2} \mathrm{O}_{3}$ were the most abundant oxides in the studied pedons. The $\mathrm{SiO}_{2}$ level in studied soils ranged from 23 to $29 \%, 17$ to $37.2 \%$ and from 31 to $36.6 \%$ in Pedons KNG-P1, KNG-P2 and GHNG-P1, respectively. The $\mathrm{Fe}_{2} \mathrm{O}_{3}$ content decreased in the order Pedon KNG-P2> Pedon KNG-P1> Pedon GHNG-P1 with pedon mean values of $41.98,38.36$ and $27.81 \%$. High values of $\mathrm{Fe}_{2} \mathrm{O}_{3}$ may be due to presence of hematite [51]. $\mathrm{Al}_{2} \mathrm{O}_{3}$ in the studied soils ranged from 15 to $21 \%, 8$ to $19 \%$ and from 12 to $15 \%$ in Pedons KNG-P1, KNG-P2 and GHNG-P1, respectively. $\mathrm{Al}_{2} \mathrm{O}_{3}$ concentration in studied rocks was $13 \%$, $13 \%$ and $0 \%$ in Pedons KNG-P1, KNG-P2 and GHNG-P1, respectively. The higher values of $\mathrm{Al}_{2} \mathrm{O}_{3}$ may originate from the presence of gibbsite. The studied soils showed higher levels of $\mathrm{CaO}$ and $\mathrm{K}_{2} \mathrm{O}$ in Pedon GHNG-P1 than in Pedons KNG-P1 and KNG-P2. This may be attributed to higher intensity of anthropogenic activities such as application of fertilizers ( $\mathrm{K}$ fertilizer) and liming material in the area represented by Pedon GHNG-P1, or may be due to deposition of colluvio-alluvium from higher lying areas [39]. The level of $\mathrm{MgO}$ and $\mathrm{Na}_{2} \mathrm{O}$ were less than 0.1 in all studied soils and rocks. The low values may be linked to low concentration of these elements in the parent rocks [51]. $\mathrm{SiO}_{2}$ level in the studied rocks ranged from 27.7 to $39.0 \%$ while $\mathrm{Al}_{2} \mathrm{O}_{3}$ ranged from 0 to $13.0 \%$. The presence of high amounts of $\mathrm{SiO}_{2}$ in soil and rock samples corresponds to amorphous silica and quartz content. High concentrations of $\mathrm{SiO}_{2}$ and $\mathrm{Al}_{2} \mathrm{O}_{3}$ in volcanic soils are probably contributed by quartz and amorphous clay minerals namely vermiculite and illite [60].

\subsection{Indices of Degree of Weathering of the Studied Soils}

Silt/clay ratio, $\mathrm{CEC}_{\text {clay }}$ and Chemical Index of Alteration (CIA) were used in this study as indices to assess the degree of weathering. The pedon mean values of silt/clay ratios were
0.98, 1.46 and 0.77 respectively for Pedon KNG-P1, Pedon KNG-P2 and Pedon GHNG-P1 (Table 3). Soils with silt/clay ratio of $<0.15$ are considered to be highly weathered [61]. Therefore, the studied soils are not highly weathered $(\mathrm{Si} / \mathrm{C}>$ 0.15). The CIA is the most widely applied and most indicative of the available weathering indices. CIA values varied somehow among studied soil pedons, with the trend KNG-P1 $>$ KNG-P2> GHNG-P1 with mean pedon values of $72.16,67.97$ and $45.98 \%$ respectively (Table 7 ). The smaller the CIA value, the younger the soils are in terms of degree of weathering and age of formation. This study showed that Pedon GHNG-P1 was less weathered than Pedons KNG-P1 and KNG-P2. This may be attributed to continuous deposition of fresh material to the site which disturbs soil development in that site and/or the site reflects the composition, properties and the degree of weathering of the transported material [39].

\subsection{Classification of the Studied Soils}

Soil morphology and physico-chemical data were used to define diagnostic horizons and other features for classifying the soils. Table 8 presents a summary of the classification. Pedon KNG-P1 had an umbric epipedon and cambic horizon as diagnostic horizons and KNG-P2 had an umbric epipedon as a diagnostic horizon. Soils represented by these pedons have been classified at the first level of the USDA Soil Taxonomy as Andisols or Andosols according to the WRB for Soil Resources. They have strong andic soil properties (bulk density $<0.9 \mathrm{~g} / \mathrm{cm}^{3}$, and $\mathrm{P}$ retention capacity $>85 \%$, high $\mathrm{pH}_{\mathrm{NaF}}>9.5$ ). Pedon GHNG-P1 has a mollic epipedon and cambic horizon as diagnostic horizons and soils represented by this pedon have been classified at the first level as Mollisols or Phaeozems according to the USDA Soil Taxonomy and WRB for Soil Resources respectively. Pedon GHNG-P1 possesses some degree of andic properties particularly in the upper $100 \mathrm{~cm}$ and has high base saturation. 
Table 8. Classification of the studied soil in Northern Province of Rwanda.

\begin{tabular}{|c|c|c|c|c|c|c|c|c|c|}
\hline \multicolumn{7}{|c|}{ USDA Soil Taxonomy [37] } & \multicolumn{3}{|c|}{ WRB for Soil Resources [38] } \\
\hline $\begin{array}{l}\text { Pedon } \\
\text { No. }\end{array}$ & $\begin{array}{l}\text { Diagnostic } \\
\text { horizon (s) }\end{array}$ & Order & $\begin{array}{l}\text { Sub } \\
\text { Order }\end{array}$ & $\begin{array}{l}\text { Great } \\
\text { Group }\end{array}$ & $\begin{array}{l}\text { Sub } \\
\text { Group }\end{array}$ & Family & $\begin{array}{l}\text { Reference } \\
\text { Soil Group } \\
\text { TIER1 }\end{array}$ & $\begin{array}{l}\text { Supplementary } \\
\text { Qualifiers }\end{array}$ & $\begin{array}{l}\text { WRB soil name - } \\
\text { TIER } 2\end{array}$ \\
\hline KNG-P1 & $\begin{array}{l}\text { Umbric } \\
\text { epipedon, } \\
\text { Cambic } \\
\text { horizon }\end{array}$ & Andisols & Udands & Fulvudands & $\begin{array}{l}\text { Pachic } \\
\text { Fulvudands }\end{array}$ & $\begin{array}{l}\text { Mountainous, } \\
\text { very deep, loamy, } \\
\text { medium acid, } \\
\text { udic, mesic, } \\
\text { Pachic } \\
\text { Fulvudands }\end{array}$ & Andosols & $\begin{array}{l}\text { Loamic, Fulvic, } \\
\text { Hyperhumic }\end{array}$ & $\begin{array}{l}\text { Dystric Umbric Vitric } \\
\text { Andosols (Loamic, Fulvic, } \\
\text { Hyperhumic) }\end{array}$ \\
\hline KNG-P2 & $\begin{array}{l}\text { Umbric } \\
\text { epipedon }\end{array}$ & Andisols & Udands & Fulvudands & $\begin{array}{l}\text { Lithic } \\
\text { Fulvudands }\end{array}$ & $\begin{array}{l}\text { Steeply dissected } \\
\text { to mountainous, } \\
\text { shallow, loamy, } \\
\text { medium acid, } \\
\text { udic, mesic, Lithic } \\
\text { Fulvudands }\end{array}$ & Andosols & $\begin{array}{l}\text { Loamic, Fulvic, } \\
\text { Hyperhumic, } \\
\text { Thixotropic }\end{array}$ & $\begin{array}{l}\text { Dystric Umbric Leptic, } \\
\text { Vitric Andosols (Loamic, } \\
\text { Fulvic, Hyperhumic, } \\
\text { Thixotropic) }\end{array}$ \\
\hline $\begin{array}{l}\text { GHNG- } \\
\text { P1 }\end{array}$ & $\begin{array}{l}\text { Mollic } \\
\text { epipedon, } \\
\text { cambic } \\
\text { horizon }\end{array}$ & Mollisols & Udolls & Hapludolls, & $\begin{array}{l}\text { Andic } \\
\text { Hapludolls }\end{array}$ & $\begin{array}{l}\text { Nearly level, very } \\
\text { deep, loamy, } \\
\text { mildly alkaline, } \\
\text { udic, thermic, } \\
\text { Andic Hapludolls }\end{array}$ & Phaeozems & $\begin{array}{l}\text { Loamic, Humic, } \\
\text { Raptic, Vitric }\end{array}$ & $\begin{array}{l}\text { Haplic Cambic Phaeozems } \\
\text { (Loamic, Humic, Raptic, } \\
\text { Vitric) }\end{array}$ \\
\hline
\end{tabular}

KNG-P1: Kinigi Pedon 1, KNG-P2: Kinigi Pedon 2, GHNG-P1=Gahunga Pedon 1

\subsection{Potentials and Limitations of the Studied Soils}

Based on the field and laboratory data, the studied soils were medium acidic to mildly alkaline. This $\mathrm{pH}$ range and high SOM associated with high CEC, high water retention and good drainage are favourable for most crops grown in the area. The low bulk densities and high porosity are essential for the expansion of plant root systems, enabling them to extract more water and nutrients from the soil. High water retention capacity enables soils to hold more water, which acts as a moisture reserve for plants during water shortage periods. Some limitations of the studied soils for agricultural production were noted. The soils represented by Pedons KNG-P1 and KNG-P2 are bound to be prone to soil erosion due to slope steepness and thixotropic properties, while the soils represented by Pedon GHNG-P1 may face flooding hazard during heavy and prolonged rains. Stoniness, shallow soils and rock outcrops limit the workability of the land and root development of some crops on soils represented by KNG-P2. Low available P, high PRC observed in soils represented by Pedon KNG-P1 and KNG-P2 and nutrient imbalances observed in the studied pedons affect negatively the production of crops grown in the area. According to the limitations and potentials mentioned, land units represented by Pedons KNG-P1 and KNG-P2 were rated as marginally suitable while the land unit represented by Pedon GHNG-P1 was rated as moderately suitable for the major crops grown in the area.

\section{Conclusions and Recommendations}

The studied soils showed a delicate ecosystem that requires careful use and management. Morphology and physico-chemical characteristics of studied soils differed from one pedon to another. Soil fertility of the studied soils is considered to be medium basing on $\mathrm{pH}$, available $\mathrm{P}, \mathrm{CEC}$,
SOM, and TN. Although the three studied pedons were developed on volcanic parent materials, they displayed different degrees of volcanic properties and only soils represented by Pedons KNG-P1 and KNG-P2 classified squarely as Andisols or Andosols according to USDA Soil Taxonomy and FAO WRB for Soil Resources respectively. Attributes observed in this study including nutrient imbalances, slope steepness and landforms, shallow and stony soils all lower the production potential of an area. These can be ameliorated by applying fertilizers; organic and inorganic, crop rotation and introduction of leguminous cover crops in the farming system. Construction of drainage systems is recommended to control water levels during the rainy season in area susceptible to flooding; terracing and terrace stabilization are highly recommended in the areas susceptible to erosion. In the area with shallow soils, adoption of shallow rooted crops and cultivation on small ridges is highly recommended so that the crops can make use of nutrients available at shallow depth.

\section{Acknowledgements}

The authors greatly appreciate the assistance received from the Alliance for Green Revolution in Africa (AGRA) through its Soil Health Project (Number 2013SHP009) for sponsoring the research.

\section{References}

[1] Twagiramungu, F. (2006). Environmental profile of Rwanda. Kigali, Rwanda. 72pp.

[2] Rushemuka, P. N., Bock, L. and Mowo, J. G. (2014). Soil science and agricultural development in Rwanda: state of the art. A review. Biotechnology Agronomy Society and Environment 18 (1): 142-154. 
[3] Van Wambeke L. (1963). Cartes des sols et de la végétation du Congo, du Rwanda et du Burundi: note explicative de la carte des sols du Rwanda et du Burundi. Bruxelles, INEAC, Belgium. 67pp.

[4] Mizota, C. and Chapelle, J. (1988). Characterization of some andepts and andic soils in Rwanda, Central Africa. Geoderma 41: $193-209$.

[5] Shoji, S, M. Nanzyo, M. and Dahigren, R. A. (1993). Volcanic ash soils: Genesis, properties and utilization. Elsevier, Amsterdam. 277pp.

[6] Ugolini, F.C. and Dahlgren, R. A. (2002). Soil development in volcanic ash. Global Environmental Research 6: 69-81.

[7] Msanya, B. M., Otsuka, H., Araki. S. and Fujitake. N. (2007). Characterization of volcanic ash soils in southwestern Tanzania: Morphology, physicochemical properties, and classification. African Study Monographs Supply 34: 39-55.

[8] McDaniel, P. A., Lowe, D. J, Arnalds, O. and Ping C.L. (2012). Andisols. In Handbook of Soil Science, $2^{\text {nd }}$ edition. (Edited by Houang, P. M, Li, Y and Sumner, M.E). Taylor and Francis: Landon. 29-44pp.

[9] Mbonigaba, J. and Culot, M. (2010). Reclamation of an acidic soil of Rwanda's central upland by composts based on natural vegetation biomass. Rwanda Journal 17: 64-81.

[10] Verdoodt, A. and Van Ranst, E. (2003). Land evaluation for agricultural production in the tropics: a large scale land suitability classification for Rwanda. Ghent University, Laboratory of Soil Science.Gent, Belgium. 173pp.

[11] Kiakojouri, A. and Taghavi Gorgi, M. M. (2014). The effects of land use change on the soil physical and chemical properties and fertility of soil in Sajadrood catchment. Agriculture Engineering International: CIGR Journal 16 (3): 10-16.

[12] Mukhlis, Nasution, Z. and Mulyanto,B. (2014). Effects of Land Use on the Physico-Chemical Properties of Andisols in Mt. Sinabung, North Sumatera, Indonesia. Malaysian Journal of Soil Science 18: 51-60

[13] Bridges, E. M. and de Bakker. H. (1997). Soils as an artefact: human impacts on the soil resource. The Land 1: 197-215.

[14] Msanya, B. M., Kaaya, A. K., Araki, S., Otsuka, H. and Nyadzi, G. I. (2003). Pedological characteristics, general fertility and classification of some benchmark soils of Morogoro District, Tanzania. African Journal of Science and Technology 2: 101-112.

[15] FAO. (2006). Guidelines for Soil Description. $4^{\text {th }}$ Edition. Food and Agriculture Organization of the United Nations Rome. 97pp

[16] Munsell Color Company (1992). Munsell Soil Color Charts. Baltimore, Maryland. Lincoln, NE.

[17] Blake, G. R. and Hartge, K. H. (1986). Bulk Density. In: Methods of Soil Analysis, Part 1, $2^{\text {nd }}$ edition, Agronomy Monograph No. 9. (Edited by Klute, A.). American Society of Agronomy and Soil Science Society of America, Madison, Wisconsin. pp 364-376.

[18] Baize D. (1993). Soil science analysis. A guide to correct use. John Wiley and Sons Ltd. West Sussex. 192pp.

[19] Klute, A. (1986). Water retention. In: Methods of Soil Analysis, Part 1, $2^{\text {nd }}$ Edition, Agronomy Monograph No. 9:
(Edited by Klute, A.). American Society of Agronomy and Soil Science Society of America, Madison, Wisconsin. pp. 635-662.

[20] National Soil Service (1990). Laboratory Procedures for Routine Soil Analysis. $3^{\text {rd }}$ edition. Agricultural Research Institute, MlinganoTanga, Tanzania. 212pp.

[21] Bouyoucos, G. J. (1962). Hydrometer method improved for making particle size analysis of soils. Agronomy Journal 54: 464-465.

[22] USDA (1975). Soil Taxonomy. A basic system of soil classification for making and interpret soil surveys. Agricultural Handbook No. 436. Washington D.C. 754pp.

[23] McLean, E. O. (1986). Soil $\mathrm{pH}$ and lime requirement. In: Methods of Soil Analysis, Part 2, $2^{\text {nd }}$ edition, Agronomy Monograph No. 9 (Edited by Page, A. L., Miller, R. H. and Keeney, D. R.). American Society of Agronomy and Soil Science Society of America, Madison, Wisconsin. pp. 199223.

[24] Moberg, J. (2000). Soil and Plant Analysis Manual. The Royal Veterinary and Agricultural University Chemistry Department, Copenhagen, Denmark. 133pp.

[25] Fieldes, M. and Perott, K. W. (1966). The nature of allophane in soils. Part 3: Rapid field and laboratory test for allophane. New Zealand Journal of Soil Science 9: 623 - 629.

[26] Nelson, D. W. and Sommers, L. E. (1982). Total carbon, organic carbon and organic matter. In: Methods of Soil Analysis, Part 2, $2^{\text {nd }}$ Edition, Agronomy Monograph No. 9 (Edited by Page, L. A. Miller, R. H. and Keeney, D. R.). American Society of Agronomy and Soil Science Society of America, Madison, Wisconsin. pp. 539-579.

[27] Duursma, E. K. and Dawson, R. (Eds) (1981). Marine organic chemistry: Evolution, composition, interactions and chemistry of organic matter in seawater. Elsevier, Amsterdam. 521pp.

[28] Bremner, J. M. (1996). Nitrogen Total. In: Methods of Soil Analysis, Part 3 Chemical Methods; (Edited by Sparks, D. L.). Soil Science Society of America, Madison, Wisconsin, 1085$1121 \mathrm{pp}$

[29] Bray, R. H. and Kurtz, L. T. (1945). Determination of total organic and available phosphorus in soils. Soil Science 59: $39-45$.

[30] Okalebo, J. P, Gathua, K. W. and Woomer, P. L. (2002). Laboratory methods of soil and plant analysis: A working manual. $2^{\text {nd }}$ edition. TSBF- SACRED Africa, Nairobi, Kenya. $128 \mathrm{pp}$.

[31] Honna, T., Yamamoto, S. and Matsui, K. (1988). A simple procedure to determine melanic index that is useful for differentiating melanic from fulvic Andisols. Pedologist 32: 69-78.

[32] Chapman, H. D. (1965). Cation exchange capacity. In: Methods of Soil Analysis, Part 1, $1^{\text {st }}$ edition, Agronomy Monograph no. 6. (Edited by Black, C.). American. Society of Agronomy, Madison, Wisconsin. 9: 891-901.

[33] Thomas, G. W. (1982). Exchangeable cations. In: Methods of Soil Analysis. Part 2, 2nd edition., Agronomy Monograph No. 9. (Edited by Page, L. A. Miller, R. H. and Keeney, D. R.). American Society of Agronomy and Soil Science Society of America, Madison, Wisconsin. pp. 595-624. 
[34] Lindsay, W. L. and Norvell, W. A. (1978). Development of DTPA soil test for Zn, Fe, Mn and Cu. Soil Science Society of American Journal 42: 421-428.

[35] Blakemore, L. C., Searle, P. L. and Daly, B. K. (1981). Methods for Chemical Analysis of Soils, New Zealand Soil Bureau Scientific Report 10A. Department of Scientific and Industrial Research, New Zealand. 81pp.

[36] Nesbitt, H. W. and Young, G. M. (1982). Early Proterozoic climates and plate motions inferred from major element chemistry of lutites. Nature 199: 715-717.

[37] Soil Survey Staff (2014). Key to Soil Taxonomy. $12^{\text {th }}$ edition. United States Department of Agriculture, Natural Resources Conservation Service.

[38] IUSS Working Group WRB (2015).World Reference Base for Soil Resources2014, update 2015. International soil classification system for naming soils and creating legends for soil maps. World Soil Resources Reports No. 106. FAO, Rome, Italy.

[39] Uwitonze, P. (2016). Morphology, physico-chemical properties and classification of the soils developed on volcanic parent materials of Northern Province of Rwanda. MSc (Soil Science and Land Management) Dissertation. Department of Soil and Geological Sciences, Sokoine University of Agriculture, Morogoro, Tanzania. 98pp.

[40] Nanzyo, M. (2002). Unique properties of volcanic ash soil. Grobal Environmental Research 6: 99-112.

[41] Yatno, E. and Zauyah, S. (2008). Properties and management implications of soils formed from volcanic materials in Lembang area,West Java. Indonesian Journal of Agricultural Science 9 (2): 44-54.

[42] Brady, N. C. and Weil, R. R. (2008). The Nature and Properties of Soils. $14^{\text {th }}$ edition. Pearson Prentice Hall, Upper Saddle River, New Jersey. 975pp.

[43] Ball, B. C. and Sullivan, M. F. (1982). Soil strength and crop emergence in direct drilled and ploughed cereal seedbeds in seven field experiments. Journal of Soil Science 33: 609-622

[44] Cass, A. (1999). Interpretation of some soil physical indicators for assessing soil physical fertility. In: Soil analysis: An interpretation manual. $2^{\text {nd }}$ edition, (Edited by Peverill, K. I., Sparrow, L. A. and D. J. Reuter, D. J.). CSIRO Publishing, Melbourne. pp. 95-102.

[45] Lal, R. and Shukla, M. K. (2004). Principles of soil physics. Marcel Dekker, Inc. New York. Basel. 716pp.

[46] Dejarme-Calalang, G. M. and Colinet, G. (2014). A review of soils and crops in the Bukidnon Highlands of Northern Mindanao, the Philippines. Biotechnology Agronomy Society and Environment 18 (4): 544-557.

[47] Poudel, D. D. and West, L. T. (1999). Soil development and fertility characteristics of a volcanic slope in mindanao, the Philippines. Soil Science Society of America Journal 63: 12581273

[48] Msanya, B. M., Kimaro, D. N., Kimbi, G. G, Kileo, E. P. and Mbogoni, J. D. J. (2001). Land resources inventory and suitability assessment for the major land use types in Morogoro Rural District, Tanzania. Soils and Land Resources of Morogoro Rural and Urban Districts, Volume 1.
Department of Soil Science, Faculty of Agriculture, Sokoine University of Agriculture, Morogoro, Tanzania. 73pp.

[49] EUROCONSULT (1989). Agriculture Compendium for Rural Development in the Tropics and sub tropics: $3^{\text {rd }}$ Revised edition. Elsevier, Amsterdam. Oxford. New York. Tokyo. 740pp.

[50] Bohn, H. J., McNeal, B. L. and O'Connor, G. A. (1985). Soil Chemistry. 2nd edition. Wiley Interscience Publication. New York. 341pp.

[51] Msanya, B. M., Munishi, J.A., Amuri, N. Semu,E., Mhoro,L. and Malley, Z. (2016) morphology, genesis, physico-chemical properties, classification and potential of soils derived from volcanic parent materials in selected districts of Mbeya region, Tanzania. International Journal of Plant and Soil Science 10 (4): 1-19.

[52] Landon, J. R. (1991) (Ed.). Booker Tropical Soil Manual. A handbook for soil survey and agricultural land evaluation in the tropics and subtropics. Longman Scientific \& Technical Publishers, Essex. 474pp.

[53] Van Wambeke, A. R. 1992. Soils of the Tropics: Properties and appraisal. McGraw-Hill Inc., New York. 343 pp.

[54] Metson, A. J. (1961). Methods of chemical analysis for soil survey samples. Soil Bureau Bulletin No. 12, New Zealand Department of Scientific and Industrial Research. Wellington, New Zealand. pp. 168-175.

[55] Vanlauwe B, Tittonell P, Mukalama J. (2006) Within-farm soil fertility gradients affect response of maize to fertilizer application in western Kenya. Nutrient Cycling in Agroecosystems 76: 171-182

[56] FAO (2008). Guide to laboratory establishment for plant nutrient analysis. FAO fertilizer and plant nutrition bulletin 19. Rome, Italy. 204pp.

[57] Magoggo, J.P., Msanya, B. M. and Kimaro, D. N. (1996). Environmental profile for agricultural production and development of conservation strategies in Mahege Village, Mbinga District, Tanzania. Technical Report No 3. Department of Soil Science, Faculty of Agriculture, Sokoine University of Agriculture, Morogoro, Tanzania and Ministry of Agriculture, National Soil Service, Agricultural Research Institute, Mlingano, Tanga, Tanzania. 38pp.

[58] Edem, S. O. and Ndaeyo, N. U. (2009). Fertility status and management implications of wetland soils for sustainable crop production in Akwa Ibom State, Nigeria. Environmental Development Sustainability. 11: 393-406.

[59] Jones, A., Breuning-Madsen, H., Brossard, M., Dampha, A., Deckers, J., Dewitte, O., Gallali, T., Hallet, S., Jones, R., Kilasara, M., Le Roux, P., Micheli, E., Montanarella, L., Spaargaren, O., Thiombiano, L., Van Ranst, E., Yemefack, M. and Zougmore, R. (Eds) (2013). Soil Atlas of Africa. European Commission, Publications Office of the European Union, Luxemborg. $176 \mathrm{pp}$.

[60] Baba, M., Hennie, F.W., Soehady, E. and Sanudin, T. (2008). Geochemical characterization of volcanic soils from Tawau, Sabah. Geological Society of Malaysia. Bulletin. 54: 33-36.

[61] Van Wambeke, A. R. (1962). Criteria for classifying tropical soils by age. Journal of Soil Science 13 (1): 124 - 132. 